\title{
MEMAKNAI CHECKLIST BAGI MAHASISWA KEDOKTERAN DAN PROFESI KESEHATAN: RESENSI BUKU
}

\author{
Carolyn, Kevin Yulianto, Elisabeth Rukmini \\ Medical Education Unit, Fakultas Kedokteraan Universitas Katolik Indonesia Atmajaya Jakarta
}

\section{IDENTITAS BUKU}

$\begin{array}{lll}\text { Judul buku } & : & \text { The Checklist Manifesto, } \\ & & \text { How to Get Things Right } \\ & \\ \text { Penulis } & : & \text { Atul Gawande } \\ \text { Penerbit } & : & \text { Metropolitan Books } \\ \text { Tahun terbit } & : & 2010 \\ \text { Tebal buku } & : & 240 \text { halaman } \\ \text { ISBN } & : & 978-0-8050-9174-8\end{array}$

\section{ULASAN BUKU}

Bidang kedokteran merupakan ilmu yang sejak lama berdiri dengan otonomi yang sangat tinggi pada tiap individu yang berkarya di dalamnya. Dokter yang terlibat dengan pasiennya, akan memutuskan tindakan yang diperlukan sesuai dengan kebutuhan pasien sejauh pengamatan dokter. Namun tak dapat dipungkiri, bahwa setiap pribadi memiliki kelemahan dalam melakukan rutinitas karya yang telah begitu lama dilakukan, tanpa sadar pribadi ini dapat melewatkan prosedur rutin, hingga mungkin saja keputusan yang dianggap terbaik, bisa menghasilkan hal yang berlawanan.

Atul Gawande dalam bukunya menceritakan tentang berbagai peristiwa tidak terduga yang terjadi dalam rutinitas karya bidang kedokteran. Rutinitas yang dilakukan karena kecerobohan atau ketidak telitian seseorang dapat berdampak pada orang lain, dalam hal ini pasien yang hidupnya bergantung pada tiap keputusan dan tindakan dokter. Dimulai dari pengalamannya sebagai dokter bedah, Atul Gawande menceritakan kompleksnya manajemen yang harus dilakukan seorang dokter terhadap pasiennya dan mudahnya seorang dokter dapat tertipu oleh gejala pasien. Dalam bidang medis penanganan yang cepat dan tepat diperlukan pasien-

Korespondensi: carolyn.ai.ling@gmail.com

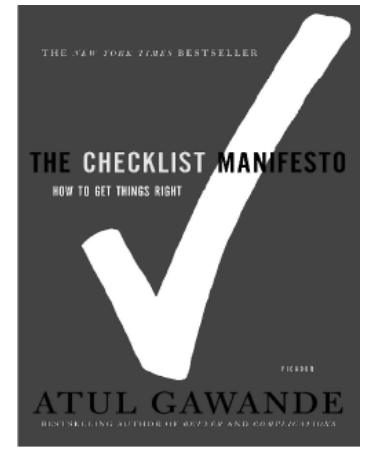

pasien UGD maupun bedah, kesalahan yang kecil dalam tindakan medis atau keluputan seorang dokter melakukan anamnesis dapat mengakibatkan kelumpuhan bahkan kematian pasien.

Tak banyak berbeda, seorang pilot pun memiliki tanggung jawab yang besar kepada penumpang yang ada di dalam pesawat yang dikemudikannya. Pengalaman bertahun-tahun mengemudikan pesawat tentu penting dalam hal ini, begitu juga keterampilan yang diperlukan dalam menerbangkannya. Sebelum pesawat lepas landas, ada begitu banyak hal yang perlu dipersiapkan, dari memeriksa mesin sampai memastikan semua pintu sudah tertutup dengan baik. Begitu juga dalam keadaan darurat, mereka harus melakukan prosedur yang benar untuk menyelamatkan penumpang dan petugas yang ada di pesawat itu. Mereka berpegang pada checklist dalam melakukan hal tersebut.

Gawande melakukan wawancara dan observasi mendalam pada profesi-profesi serupa dengan bidang profesi kedokteran, yang memiliki tanggung jawab terhadap kompleksitas yang tidak terduga. Ia membukukan pengalaman para pilot, para pembangun gedung pencakar langit (skyscraper), para chef professional. Dari pengalamannya tersebut Gawande berusaha mencari kesamaan solusi yang praktis, murah, dan mudah diterapkan dalam situasi kompleks, baik di negara berkembang maupun negara maju untuk mengoptimalkan kinerja seorang profesional dan 
meminimalkan kesalahan-kesalahan. Gawande menuliskan bahwa masalah yang ditemukan seringkali bukanlah karena kurangnya pengetahuan tentang cara menyelesaikan problem yang kompleks tersebut, melainkan kurangnya kemampuan menerapkan pengetahuan dengan praktik. Jawaban dari masalah tersebut adalah "checklist". Checklist merupakan daftar serangkaian proses yang harus dilakukan untuk memperlancar suatu tindakan.

Atul Gawande memaparkan dengan cerita-cerita singkat yang menarik tentang bagaimana checklist dapat menyelamatkan jiwa seorang anak yang tenggelam sampai ratusan orang di dalam pesawat terbang yang mengalami mati mesin. Dalam bidang medis ia bekerja sama dengan WHO dalam penelitian di berbagai negara. Pada sebuah percobaan yang dilakukannya bersama WHO, Atul Gawande membuat checklist untuk memudahkan kerja dokter dalam melakukan pembedahan. Checklist yang dibuatnya bertujuan untuk meningkatkan kerja tim dengan cara saling memperkenalkan diri dan menjelaskan perannya dalam operasi yang dilakukan dan juga membantu dokter dalam melakukan prosedur rutin yang benar dari sebelum, sedang dan sesudah operasi berjalan dengan membacakan checklist yang sudah dibuat kepada tim yang bekerja sama pada tiap tahapnya. Implementasi checklist ini diharapkan dapat menurunkan presentase kecelakaan yang terjadi akibat kesalahan prosedur bedah yang mungkin terjadi akibat kelalaian tenaga medis seperti lupa memberikan antibiotik kepada pasien sebelum operasi, untuk mengurangi resiko infeksi atau menyediakan donor darah sebagai bentuk pencegahan jika terjadi sesuatu yang tidak diinginkan. Hal-hal tersebut adalah hal yang biasa dipandang remeh oleh tenaga profesional kesehatan yang melakukan operasi karena dianggap sebagai rutinitas biasa. Tujuan utama dari checklist ini bukan hanya untuk memberi tanda pada kotak yang disediakan tetapi juga menghasilkan kerja sama dan disiplin yang baik dalam tim.

Percobaan pertama tersebut tidak segera ditanggapi dengan serius, tenaga kesehatan merasa ragu akan efektivitas checklist yang dicoba pada 8 rumah sakit berbeda yang tersebar di beberapa negara baik negara maju, negara berkembang dan negara dunia ketiga. Pada awalnya ada kekhawatiran perbedaan cara pandang dalam implementasi checklist dan efektivitasnya di negara berkembang dibandingkan di negara maju. Dalam hal jumlah tenaga medis, jumlah pasien yang dilayani, dan prosedur yang dilakukan, keadaan di negara berkembang seperti India atau Tanzania pasti jauh berbeda dengan di London atau Toronto. Selain itu, efektivitas teknis checklist juga perlu dilihat dari susunan kalimat, siapa yang membuatnya, kepraktisan, kejelasan, keringkasan, siapa yang membacakannya, siapa yang menindaklanjutinya. Setelah proses review dan revisi checklist, akhirnya program checklist siap diimplementasikan. Dengan bantuan dari tim peneliti yang hanya terdiri dari 4 orang, ditemukan hasil di luar bayangan sebelumnya. Angka kematian dan kecelakaan yang disebabkan oleh operasi menurun dengan signifikan. Namun masih ada beberapa hal yang menjadi pertanyaan terkait efektivitas checklist. Memang dapat diakui bahwa dengan adanya checklist ini, beberapa tindakan profilaksis yang tadinya sering dilupakan, dapat diatasi dengan baik, tetapi tak dapat dimungkiri pula, bahwa checklist ini tidak memiliki hubungan dengan jumlah darah yang keluar dari tubuh pasien, walaupun data menunjukkan penurunan.

Sebagai tambahan, tim peneliti yang dipimpin oleh Atul Gawande memberikan kuisioner kepada personel tim operasi, yang terlibat pada program percobaan WHO ini. Peneliti mengumpulkan pendapat tim operasi tentang penggunaan checklist dan prosedurnya. Banyak dari perawat yang ikut dalam tim operasi merasakan bahwa checklist ini memberikan efek pada kinerja tim, mengingat keberadaan perawat yang jarang diperhitungkan, tapi di lain pihak, dokter bedah yang terlibat merasa risih dengan adanya checklist karena tidak sesuai dengan kebiasaan yang mereka lakukan, karena bagaimana pun juga tiap dokter memiliki caranya sendiri dalam melakukan operasi. Tetapi ketika sampai pada pertanyaan "apakah anda mau menggunakan checklist ini pada tindakan operasi anda?" sebanyak 93\% responden menjawab "ya”. Selain itu, Gawande melaporkan dengan menerapkan checklist ini, tim medis berhasil meminimalkan angka infeksi nosokomial dan angka kesalahan tindakan medis di rumah sakit tempat ia bekerja. Dari hasil penelitian yang dilakukannya dengan WHO ia memaparkan data yang menunjukkan pentingnya checklist dalam dunia medis terlepas dari lokasi 
dan jumlah karyawan atau tenaga kesehatan di suatu rumah sakit.

Buku ini membuka perspektif terutama dalam kegiatan para profesional, tidak terbatas dalam bidang kedokteran saja. Bidang lainnya seperti kontraktor raksasa, kuliner profesional, pilot juga diungkapkan dengan sangat menarik. Para profesional ini mampu mengelola keadaan yang kompleks dengan sederhana melalui bantuan checklist. Melalui cerita-cerita yang menggugah pembaca, Gawande berhasil memberikan argumen kuat dan judul buku ini cukup provokatif serta terbukti baik dan benar. Satu kekurangan buku ini adalah kurangnya penjelasan penulis terhadap istilah-istilah medis dan efek suatu tindakan pada pasien sehingga dapat membingungkan masyarakat awam. Secara keseluruhan buku ini menarik dan mengajak berpikir pembaca bagaimana checklist dapat diterapkan dalam bidang pekerjaan pembaca masing-masing.

\section{PEMBAHASAN}

Bagi mahasiswa kedokteran dan profesi kesehatan buku ini dapat digunakan sebagai sarana pendidikan misalnya pada blok-blok awal semester pertama untuk memperkenalkan profesi kedokteran dan bidang kesehatan. Selain itu dapat juga diterapkan pada blok semacam infeksi atau kedokteran tropis untuk memperkenalkan prosedur teknis bagi pengurangan infeksi nosokomial secara massal dan praktis. Mahasiswa kepaniteraan juga perlu membaca buku ini sebagai bahan independen dan diskusi kelompok sebelum masuk ke klinik, sehingga ada gambaran pentingnya prosedur sederhana tetapi bermakna bagi praktik kedokteran dan bidang kesehatan.

Checklist pun memiliki kekurangan. Gawande ${ }^{1}$ menyatakan bahwa checklist hanyalah sebuah alat yang digunakan untuk mengingatkan mengenai tugas yang seharusnya dilakukan. Checklist sebagai alat tersebut dapat berperan dalam hal-hal yang kompleks. Meskipun demikian, interpretasi dan praktik menggunakan checklist tidak bergantung pada kata-kata yang ada di dalamnya, melainkan dipengaruhi oleh orang-orang yang ada dan bertindak pada saat penggunaannya.

Secara praktis dan kontinu, dalam pembelajaran bidang kedokteran penggunaan checklist dalam melakukan prosedur atau tindakan memiliki berbagai kelebihan dan kekurangan. Checklist memberi panduan dan membantu mahasiswa kedokteran tentang bagaimana suatu pemeriksaan harus dilakukan, langkah-langkah yang perlu dilakukan, dan sistematika pemeriksaan. Dengan adanya checklist mahasiswa dapat berpikir lebih sistematis dan terstruktur dalam belajar suatu prosedur, contohnya dalam Skills Lab. Dalam kegiatan Skills Lab mahasiswa dapat mempelajari checklist tindakan yang perlu dilakukan dan langkah-langkahnya terlebih dahulu sebelum melakukan simulasi kepada pasien standar. Dalam simulasi prosedur Skills Lab maupun OSCE, checklist juga digunakan untuk menilai ketepatan dan kelengkapan tindakan yang dilakukan mahasiswa dalam melakukan suatu prosedur.

Kelebihan lain penggunaan checklist selain sebagai panduan teknis, juga meningkatkan partisipasi mahasiswa dalam melakukan tindakan yang lebih kompleks terutama di tingkat pendidikan klinik. Telaah sistematik ${ }^{2}$ menemukan hampir seluruh checklist (97\%) memuat kompetensi prosedural. Penelitian lain mengungkapkan kisah sukses serupa, setelah percobaan selama satu tahun menggunakan checklist di ruang operasi, staf operasi yang terdiri dari dokter bedah, dokter anestesi, perawat, dan asisten merespon positif penggunaan checklist dalam mengidentifikasi kemungkinan kesalahan dalam tindakan yang akan dilakukan. ${ }^{3}$ Penggunaan checklist juga menurunkan signifikan angka kejadian kecelakaan pasien dan meningkatkan outcome pasien secara keseluruhan. ${ }^{4}$ Meskipun demikian, kajian sistematik juga menyoroti minimnya kompetensi teamwork (15\%) dan infection control (32\%) pada checklist pendidikan kedokteran terutama di tingkat klinik.

Tantangan terhadap checklist sebagai alat penilaian juga telah diteliti. ${ }^{5,6}$ Dalam penilaian terhadap performa mahasiswa untuk melakukan tindakan medis, checklist atau cara penilaian obyektif lainnya tidak memberikan hasil yang lebih baik daripada penilaian subyektif pasien standar. Modifikasi penilaian psikomotor terus dilakukan, ${ }^{5}$ termasuk di dalamnya pilihan menggunakan global rating, standardized assessor, dan perkembangan teknologi mendorong pula alat penilai yang lebih userfriendly serta praktis. ${ }^{7}$ Untuk mengatasi keluhan terhadap mahasiswa pengguna checklist yang dinilai terlalu kaku, maka komponen naratif perlu dimasukkan dalam 
penilaian. Umpan balik dari penilai sebagai tambahan penilaian dengan checklist menjadi pilihan yang baik dan mendorong perbaikan kualitas psikomotorik mahasiswa. ${ }^{8}$ Solusi atas kekurangan checklist sebagai langkah prosedural dan alat penilaian bagi mahasiswa perlu dilandasi terutama dengan kontekstualitas ilmu dan keterampilan. Mahasiswa kedokteran dan bidang kesehatan perlu panduan, tidak terbatas pada checklist keterampilan yang harus dikuasai, namun harus didasarkan pada rasa ingin tahu mahasiswa dan relevansinya dengan konteks nyata yang akan ditemui di klinik. Oleh karenanya, penggalian mengenai clinical reasoning juga merupakan salah satu bentuk penilaian pendamping yang penting di samping penilaian berbasis checklist. Jika hal ini digali setelah mahasiswa menjalani OSCE, maka tambahan aspek konstekstual ujian menjadi bermakna. ${ }^{9}$ Dengan menggali alasan untuk belajar suatu keterampilan, pembelajaran akan lebih diingat dan berguna bagi mahasiswa.

Checklist pun memiliki kekurangannya sendiri. Gawande ${ }^{1}$ menyatakan bahwa checklist hanyalah sebuah alat yang digunakan untuk mengingatkan mengenai tugas yang seharusnya dilakukan. Checklist sebagai alat tersebut dapat berperan dalam hal-hal yang komplek. Meskipun demikian, interpretasi dan praktik menggunakan checklist tidak bergantung pada kata-kata yang ada di dalamnya, melainkan dipengaruhi oleh orang-orang yang ada dan bertindak pada saat penggunaannya. Penyusunan checklist yang baik dalam bidang pendidikan kedokteran maupun praktik kedokteran dan bidang kesehatan menurut Gawande ${ }^{1}$ perlu dilakukan. Berdasarkan pengalamannya, checklist general surgery seperti dalam lampiran bukunya dibuat berkali-kali dan melalui test-retest berdasarkan masukan ahli dan pengguna. Prinsip yang sama juga diperlukan saat mendesain checklist untuk penilaian hasil belajar mahasiswa kedokteran dan bidang kesehatan. Isi checklist tidak semata disusun berdasarkan segi praktis tetapi juga sisi ilmiah menyertakan evidenced-based medicine. ${ }^{10}$ Checklist sebagai alat penilai juga perlu diuji validitas dan reliabilitasnya ${ }^{11,12}$ sehingga dapat menjadi alat ukur yang diakui sebagai standar seperti Global Rating Scale dan Procedure-Based Assessment yang sudah diakui sebagai standar kelas satu Accreditation Council for Graduate Medical Education (ACGME), ${ }^{5,13}$ Oleh karenanya, rekam jejak desain dan penggunaan checklist perlu dibukukan. Penelitian bidang pendidikan kedokteran dan profesi kesehatan terutama tentang penilaian mahasiswa dapat melakukan dan mempublikasikan laporan terkait.

Checklist dalam pendidikan kedokteran dan profesi kesehatan seringkali tidak sama di berbagai negara. Muatan sosial budaya memberikan pengaruh pada interaksi antar manusia termasuk didalamnya unsurunsur prosedural bidang kedokteran. ${ }^{1,6}$ Oleh karenanya, penyusunan checklist di negara maju dan dunia Barat tidak selalu dapat dipakai seutuhnya dalam situasi dengan nilai-nilai yang beragam. Peliknya penyusunan checklist ini kemudian perlu diselesaikan dalam kerja tim yang komprehensif, test-retest, revisi, rekam jejak, dan pelaporan implementasi. Hal ini kemudian dipadukan dengan masukan naratif atau umpan balik kualitatif yang bergantung pada penguji. Bias subyektivitas mungkin saja ada, oleh karena itu solusi yang ditawarkan adalah standarisasi penguji melalui serangkaian ujicoba dan latihan..$^{14}$

Daftar pernyataan yang terdapat dalam checklist, menentukan tindakan yang perlu dilakukan mahasiswa dalam mengerjakan skill yang sedang dilatihnya. Pernyataan pada checklist itu dibuat berdasarkan pandangan ahli mengenai skills terkait, data penelitian, sumber literatur, guidelines, dan juga hasil dari pilot-testing yang dilakukan berulang kali sebelum checklist difinalisasi. ${ }^{10}$ Pandangan ahli yang dibutuhkan untuk membuat checklist, tentu tidak hanya satu orang saja. Dalam hal ini, para ahli tentu memiliki pandangannya sendiri mengenai prosedur yang diperlukan dalam melakukan skills tertentu berdasarkan pengalaman mereka dan organisasi profesional yang mereka ikuti. Perkembangan bidang kedokteran dan kesehatan menuntut pihak-pihak terkait di dalamnya untuk tidak berhenti belajar termasuk meninjau ulang checklist dari waktu ke waktu sesuai bukti literatur. ${ }^{10}$ Oleh karena itu, perlu adanya keseimbangan antara pandangan ahli dan tindakan yang telah dibuktikan dalam literatur.

Sebagai pembelajar dewasa, checklist juga dapat digunakan dalam melakukan tugas sehari-hari, baik dalam melakukan pekerjaan sederhana sampai dengan proyek yang besar. Dalam bukunya Getting Things Done, David Allen ${ }^{15}$ menguraikan pentingnya menuliskan dalam 
kertas, proyek-proyek yang belum diselesaikan dan halhal lain yang membebani pikiran kita. Kemudian kita perlu memberi prioritas terhadap proyek-proyek penting yang ingin dilakukan terlebih dahulu. Setelah memilih proyek yang ingin dikerjakan, kita perlu memecah proyek tersebut menjadi bagian-bagian yang lebih kecil sampai kepada tindakan yang dapat dilakukan untuk menyelesaikan proyek tersebut. Dengan menguraikan suatu proyek abstrak menjadi daftar tindakan nyata yang dapat dilakukan, maka kita dapat menyelesaikan suatu proyek dengan lebih terstrukur dan cepat, sekaligus juga menurunkan tingkat stress dan meningkatkan hasil yang didapat.

\section{DAFTAR PUSTAKA}

1. Gawande A. The Checklist manifesto: how to get things right. New York: Picador; 2010.

2. McKinley RK, Strand J, Ward L, Gray T, Alun-Jones T, Miller H. Checklists for assessment and certification of clinical procedural skills omit essential competencies: a systematic review. Med Educ. 2008;42(4):338-49.

3. Nilsson L, Lindberget O, Gupta A, Vegfors M. Implementing a pre-operative checklist to increase patient safety: a 1-year follow-up of personnel attitudes. Acta Anaesthesiol Scand. 2010;54(2):17682.

4. Hales BM, Pronovost PJ. The checklist-a tool for error management and performance improvement. J Crit Care. 2006;21(3):231-5.

5. Jelovsek JE, Kow N, Diwadkar GB. Tools for the direct observation and assessment of psychomotor skills in medical trainees: a systematic review. Med Educ. 2013;47(7):650-73.

6. Whitehead CR, Kuper A, Hodges B, Ellaway R. Conceptual and practical challenges in the assessment of physician competencies. Med Teach. 2014;1-7.
7. Ferenchick GS, Solomon D, Foreback J, Towfiq B, Kavanaugh K, Warbasse L, et al. Mobile technology for the facilitation of direct observation and assessment of student performance. Teach Learn Med. 2013;25(4):292-9.

8. Van Nuland M, Van den Noortgate W, van der Vleuten C, Jo G. Optimizing the utility of communication OSCEs: omit station-specific checklists and provide students with narrative feedback. Patient Educ Couns. 2012 Jul;88(1):10612.

9. Durning SJ, Artino A, Boulet J, La Rochelle J, Van der Vleuten C, Arze B, et al. The feasibility, reliability, and validity of a post-encounter form for evaluating clinical reasoning. Med Teach. 2012;34(1):30-7.

10. Hettinga AM, Denessen E, Postma CT. assessment: Checking the checklist: a content analysis of expertand evidence-based case-specific checklist items. Med Educ. 2010;44(9):874-83.

11. Sandilands D (Dallie), Gotzmann A, Roy M, Zumbo $\mathrm{BD}$, De Champlain A. Weighting checklist items and station components on a large-scale OSCE: Is it worth the effort? Med Teach. 2014;36(7):585-90.

12. McKinley RK, Strand J, Gray T, Schuwirth L, AlunJones T, Miller H. Development of a tool to support holistic generic assessment of clinical procedure skills. Med Educ. 2008;42(6):619-27.

13. Morris MC, Gallagher TK, Ridgway PF. Tools used to assess medical students competence in procedural skills at the end of a primary medical degree: a systematic review. Med Educ Online [Internet]. 2012 [cited 2014 Dec 31];17. Available from: http:// www.ncbi.nlm.nih.gov/pmc/articles/PMC3427596/

14. Hope D, Cameron H. Examiners are most lenient at the start of a two-day OSCE. Med Teach. 2015;37(1):81-5.

15. Allen D. Getting Things Done: How to achieve stressfree productivity. Hachette UK; 2011. 250 p. 